\title{
DETERMINAN KEJADIAN ISPA PADA BAYI DI PUSKESMAS RAWAT INAP SIMPANG TIGA PEKANBARU
}

\author{
Neneng Savitri \\ Program Studi Magister Kesehatan Masyarakat STIKes Hang Tuah, Pekanbaru, Riau, \\ Indonesia \\ Email : nenengsavitri19@gmail.com
}

\begin{abstract}
Abstrak
Infeksi Saluran Pernapasan Akut (ISPA) adalah penyakit saluran pernapasan akut yang disebabkan oleh agen infeksius yang ditularkan dari manusia ke manusia dengan gejala meliputi demam, batuk, nyeri tenggorok, coryza (pilek), sesak napas, mengi atau kesulitan bernapas. Data angka kejadian ISPA pada Bayi di Puskesmas Rawat Inap Simpang Tiga Pekanbaru tahun 2017 sebanyak 886 kasus. Penelitian ini bertujuan untuk mengetahui determinan kejadian ISPA pada bayi usia 6-12 bulan. Desain yang digunakan dalam penelitian ini adalah kuantitatif analitik observasional dengan pendekatan case control. Jumlah sampel untuk kasus dan kontrol adalah 182. Metode pengambilan sampel kasus dan kontrol dilakukan secara systematic random sampling dari masing-masing populasi. Pengolahan data secara komputerisasi. Analisis yang digunakan analisis univariat, bivariat dan multivariat. Hasil penelitian menunjukkan variabel yang paling berpengaruh terhadap kejadian ISPA pada bayi usia 6-12 bulan adalah kebiasaan merokok di dalam rumah (CI 95\% : $\mathrm{OR}=2,9-8,5)$, pendidikan ibu (CI 95\% : OR=1,6-5,9), pemberian ASI Eksklusif (CI 95\% : $\mathrm{OR}=1,2-4,5)$, luas ventilasi $(\mathrm{CI} 95 \%$ : $\mathrm{OR}=1,8-7,1)$ dan pemberian vitamin A (CI 95\% : $\mathrm{OR}=1,5-5,1)$. Disarankan kepada petugas puskesmas dan kader posyandu agar selalu rutin melakukan promosi kesehatan mengenai ISPA pada bayi terutama kepada keluarga dengan kebiasaan merokok di dalam rumah.
\end{abstract}

Kata Kunci : Kebiasaan merokok, Pendidikan Ibu, Pemberian ASI Eksklusif, Kejadian ISPA

\section{PENDAHULUAN}

Infeksi Saluran Pernapasan Akut (ISPA) didefinisikan sebagai penyakit saluran pernapasan akut yang disebabkan oleh agen infeksius yang ditularkan dari manusia ke manusia. Timbulnya gejala biasanya cepat, yaitu dalam waktu beberapa jam sampai beberapa hari. Gejalanya meliputi demam, batuk dan sering juga nyeri tenggorok, coryza (pilek), sesak napas, mengi atau kesulitan bernapas (Masriadi, 2017).

ISPA adalah salah satu penyebab utama morbiditas dan mortalitas penyakit menular di dunia. Angka mortalitas ISPA mencapai 4,25 juta setiap tahun (Najmah, 2016). Di negara- negara dengan pendapatan perkapita rendah dan menengah tingkat mortalitas sangat tinggi pada bayi, anak-anak, dan orang lanjut usia (WHO, 2007). ISPA juga merupakan salah satu penyebab utama kunjungan pasien di Puskesmas (40\%- 60\%) dan rumah sakit (15\%-30\%) (Kemenkes RI, 2012).

ISPA merupakan masalah kesehatan yang penting karena menjadi penyebab pertama kematian di Negara berkembang. Setiap tahun ada dua juta kematian yang 
disebabkan oleh ISPA. WHO memperkirakan insidensi ISPA di negara berkembang 0,29\% (151 juta jiwa) (Marni, 2014).

Salah satu negara berkembang dengan kasus ISPA yang tinggi adalah Indonesia. Indonesia selalu menempati urutan pertama penyebab kematian ISPA pada kelompok bayi dan balita (Najmah, 2016). Prevalensi ISPA di Indonesia pada tahun 2013 adalah $25,0 \%$ tidak jauh berbeda dengan prevalensi pada tahun 2007 sebesar 25,5\%. Prevalensi ISPA tertinggi terjadi pada kelompok umur 1-4 tahun sebesar 25,8\% dan $<1$ tahun sebesar 22,0\% (Kemenkes, 2013). Di Provinsi Riau prevalensi ISPA pada kelompok umur $<1$ tahun berada di angka 28,6\% (Dinkes Riau, 2013).

Data dari Dinas Kesehatan kota Pekanbaru menunjukkan, tahun 2014 hingga 2016, ISPA masih mendominasi sepuluh penyakit terbesar di puskesmas yang diderita masyarakat. Kasus ISPA pada golongan umur $<1$ tahun berjumlah 7.677 kasus (2014), 9.450 kasus (2015) dan 6.736 kasus (2016) (Dinkes Kota Pekanbaru, 2016).

Penularan infeksi saluran pernapasan akut dapat terjadi melalui air ludah, bersin, udara pernapasan yang mengandung kuman yang terhirup oleh orang sehat ke saluran pernapasannya. Infeksi saluran pernapasan terutama yang disebabkan oleh virus, sering terjadi pada semua golongan umur. ISPA yang berlanjut menjadi Pneumonia sering terjadi pada golongan umur $<1$ tahun, terutama apabila terdapat gizi kurang dan dikombinasi dengan keadaan lingkungan yang tidak hygiene seperti terdapat polusi udara dalam ruangan yang disebabkan kebiasaan merokok di dalam rumah (Sundari dkk, 2014). Selain status gizi dan terdapat asap rokok di dalam rumah, ISPA juga dipengaruhi oleh beberapa faktor risiko, diantaranya usia, jenis kelamin, pemberian ASI Eksklusif, imunisasi, berat badan lahir, pemberian kapsul vitamin A, pendidikan ibu, pekerjaan ibu, ventilasi, dan kepadatan hunian (Wijayaningsih, 2013; Marni 2014; Tosepu, 2016).

Kejadian ISPA, terutama yang terjadi pada golongan umur $<1$ tahun tetap harus diwaspadai karena berpotensi menjadi parah atau Pneumonia. Salah satu pencegahan untuk mengurangi risiko tersebut dengan pemberian ASI Eksklusif untuk meningkatkan daya tahan tubuh anak sejak dini. Zat kekebalan yang terdapat pada ASI akan melindungi dan menurunkan kemungkinan bayi terkena penyakit infeksi termasuk ISPA (Kemenkes RI, 2014).

Puskesmas Rawat Inap Simpang Tiga Pekanbaru merupakan Puskesmas dengan kasus tertinggi ISPA pada anak golongan umur $<1$ tahun dan salah satu Puskesmas dengan cakupan pemberian ASI Eksklusif yang mengalami penurunan selama 2 tahun terakhir. Kasus ISPA pada anak < 1 tahun berjumlah 996 kasus pada tahun 2016 dan 886 kasus pada tahun 2017. Selain itu, terdapat 73 kasus Pneumonia pada anak $<1$ tahun sepanjang tahun 2016-2017. Sedangkan cakupan pemberian ASI Eksklusif pada tahun 2017 sebesar 57,09 \% menurun dibandingkan dengan tahun 2016 sebesar 64,02 \% (Dinkes Kota Pekanbaru, 2016).

Berdasarkan latar belakang tersebut, maka peneliti tertarik untuk meneliti tentang Determinan Kejadian ISPA pada Bayi di Puskesmas Rawat Inap Simpang Tiga Pekanbaru Tahun 2017.

\section{METODE PENELITIAN}


Rancangan penelitian ini bersifat bersifat kuantitatif analitik observasional dengan desain case control. Populasi kasus dalam penelitian ini adalah seluruh bayi usia 6-12 bulan yang menderita ISPA dan tercatat di buku register anak Puskesmas Rawat Inap Simpang Tiga Pekanbaru pada Januari 2017 - April 2018 yang berjumlah 292 orang, sedangkan populasi kontrol yaitu seluruh bayi usia 6-12 bulan yang tidak menderita ISPA pada bulan yang sama dan tercatat di buku register anak Puskesmas Rawat Inap Simpang Tiga Pekanbaru yang berjumlah 540 orang. Jumlah sampel pada penelitian ini adalah 182 kasus dan 182 kontrol. Pengambilan sampel kasus dan kontrol dilakukan secara systematic random sampling.

Pengumpulan data dalam penelitian ini menggunakan data primer dan data sekunder. Data primer diperoleh dengan melakukan wawancara dan observasi dengan menggunakan kuesioner, sedangkan data sekunder diperoleh dari buku register anak Puskesmas Rawat Inap Simpang Tiga Pekanbaru. Variabelvariabel yang digunakan adalah kejadian ISPA sebagai variabel dependen dengan hasil ukur ISPA dan tidak ISPA, sedangkan variabel independen yaitu pemberian ASI Eksklusif dengan hasil ukur tidak ASI Eksklusif dan ASI Eksklusif, status imunisasi DPT dengan hasil ukur tidak diimunisasi dan diimunisasi, status gizi bayi dengan hasil ukur kurang baik dan baik, pemberian vitamin A dengan hasil ukur belum diberikan dan sudah diberikan, kebiasaan merokok di dalam rumah dengan hasil ukur merokok di dalam rumah dan tidak merokok di dalam rumah, luas ventilasi dengan hasil ukur tidak memenuhi syarat $(<10 \%)$ dan memenuhi syarat $(\geq 10 \%)$, berat badan lahir dengan hasil ukur rendah
$(<2500$ gram) dan Normal $(\geq 10 \%)$, jenis kelamin dengan hasil ukur laki-laki dan perempuan, pendidikan ibu dengan hasil ukur rendah (tidak sekolah, tidak tamat $\mathrm{SD}$, tamat SD SMP/sejerarat) dan tinggi (tamat SMA/sederajat, akademi/ perguruan tinggi), pekerjaan ibu dengan hasil ukur bekerja (wiraswasta,PNS, lainnya) dan tidak bekerja (IRT). Pengolahan data meliputi Menyunting data (Editing), Mengkode data (Coding), Memasukkan data (Entry), Membersihkan data (Cleaning), dan Tabulasi data (Tabulating). Analisis data dilakukan secara univariat, bivariat dilakukan dengan uji Chi Square dan multivariat dengan menggunakan Regresi Logistik Ganda.

\section{HASIL DAN PEMBAHASAN}

\section{Analisis Univariat}

Hasil analisis univariat menunjukkan bahwa bayi usia 6-12 bulan yang tidak ASI Eksklusif 73,4\%, jenis kelamin laki-laki $64,3 \%$, kebiasaan merokok di dalam rumah $49,2 \%$, bayi usia 6-12 bulan yang belum diberikan vitamin A 38,2\%, ibu bayi yang bekerja $37,7 \%$, ibu yang berpendidikan rendah $29,1 \%$, luas ventilasi rumah yang tidak memenuhi syarat $(<10 \%)$ 26,9\%. Disamping itu terdapat variabel homogen (salah satu kategori $<20 \%$ ) pada variabel independen yaitu, status imunisasi DPT, status gizi bayi dan berat badan lahir.

\section{Analisis Bivariat}

Hasil analisis bivariat menunjukkan ada 8 variabel independen yang berhubungan signifikan dengan kejadian ISPA pada bayi usia 6-12 bulan yaitu bayi usia 6-12 bulan yang tidak ASI Eksklusif (CI 95\% : OR $=2,8-8,0$ ), tidak diberikan imunisasi DPT (CI 95\% : OR = 3,6-16,1), status gizi kurang baik (CI 95\%: OR = 
(1,9-6,3), belum diberikan vitamin A (CI $95 \%:$ OR $=(2,1-5,3)$, kebiasaan merokok di dalam rumah $(\mathrm{CI} 95 \%$ : $\mathrm{OR}=(4,0-$ $10,1)$, luas ventilasi rumah yang tidak memenuhi syarat $(<10 \%)(\mathrm{CI} 95 \%: \mathrm{OR}=$
$(4,0-12,6)$, BBLR $(<2500$ gr) (CI 95\% : $\mathrm{OR}=(1,9-2,3)$, ibu bayi yang berpendidikan rendah (CI 95\%: OR = $(1,6-4,3)$.

Tabel 1 Hubungan antara Variabel Independen dengan Kejadian ISPA di Puskesmas Rawat Inap Simpang Tiga Pekanbaru

\begin{tabular}{|c|c|c|c|c|c|c|c|c|c|}
\hline \multirow{3}{*}{ No. } & \multirow{3}{*}{ Variabel Independen } & \multicolumn{8}{|c|}{ Kejadian ISPA } \\
\hline & & \multicolumn{2}{|c|}{ ISPA } & \multicolumn{2}{|c|}{ Tidak ISPA } & \multicolumn{2}{|c|}{ Total } & \multirow{2}{*}{$\begin{array}{l}\text { OR }(95 \% \\
\text { CI) }\end{array}$} & \multirow{2}{*}{ P value } \\
\hline & & $\mathbf{n}$ & $\%$ & $\mathbf{n}$ & $\%$ & $\mathbf{N}$ & $\%$ & & \\
\hline \multirow[t]{3}{*}{1} & Pemberian ASI Eksklusif & & & & & & & & \\
\hline & - $\quad$ Tidak ASI Eksklusif & 159 & 87,4 & 108 & 59,3 & 267 & 73,4 & 4,737 & $<0,001$ \\
\hline & - $\quad$ ASI Eksklusif & 23 & 12,6 & 74 & 40,7 & 97 & 26,6 & $(2,8-8,0)$ & \\
\hline \multirow[t]{3}{*}{2} & Status Imunisasi DPT & & & & & & & & \\
\hline & - $\quad$ Tidak imunisasi & 52 & 28,6 & 9 & 4,9 & 61 & 16,8 & 7,689 & $<0,001$ \\
\hline & - Diimunisasi & 130 & 71,4 & 173 & 95,1 & 303 & 83,2 & $(3,6-16,1)$ & \\
\hline \multirow[t]{3}{*}{3} & Status gizi bayi & & & & & & & & \\
\hline & - $\quad$ Kurang baik & 48 & 26,4 & 17 & 9,3 & 65 & 17,9 & 3,477 & $<0,001$ \\
\hline & - Baik & 134 & 73,6 & 165 & 90,7 & 299 & 82,1 & $(1,9-6,3)$ & \\
\hline \multirow[t]{3}{*}{4} & Pemberian vitamin A & & & & & & & & \\
\hline & - $\quad$ Belum diberikan & 95 & 52,2 & 44 & 24,2 & 139 & 38,2 & 3,425 & $<0,001$ \\
\hline & - $\quad$ Sudah diberikan & 87 & 47,8 & 138 & 75,8 & 225 & 61,8 & $(2,1-5,3)$ & \\
\hline \multirow[t]{3}{*}{5} & $\begin{array}{l}\text { Kebiasaan merokok di } \\
\text { dalam rumah }\end{array}$ & & & & & & & & \\
\hline & $\begin{array}{l}\text { - Merokok di dalam } \\
\text { rumah }\end{array}$ & 129 & 70,9 & 50 & 27,5 & 179 & 49,2 & $\begin{array}{c}6,426 \\
(4,0-10,1)\end{array}$ & $<0,001$ \\
\hline & $\begin{array}{l}\text { - } \quad \begin{array}{l}\text { Tidak merokok di } \\
\text { dalam rumah }\end{array}\end{array}$ & 53 & 29,1 & 132 & 72,5 & 185 & 50,8 & & \\
\hline \multirow[t]{3}{*}{6} & Luas ventilasi rumah & & & & & & & & \\
\hline & $\begin{array}{l}\text { - } \quad \text { Tidak memenuhi syarat } \\
(<10 \%)\end{array}$ & 80 & 44,0 & 18 & 9,9 & 98 & 26,9 & $\begin{array}{c}7,146 \\
(4,0-12,6)\end{array}$ & $<0,001$ \\
\hline & $\begin{array}{l}\text { Memenuhi syarat }(\geq \\
10 \%)\end{array}$ & 102 & 56,0 & 164 & 90,1 & 266 & 73,1 & & \\
\hline \multirow[t]{3}{*}{7} & Berat badan lahir & & & & & & & & \\
\hline & - $\quad$ Rendah $(<2500$ gr $)$ & 22 & 12,1 & 0 & 0 & 22 & 6,0 & 2,138 & $<0,001$ \\
\hline & - $\quad$ Normal $(\geq 2500$ gr $)$ & 160 & 87,9 & 182 & 100 & 342 & 94,0 & $(1,9-2,3)$ & \\
\hline \multirow[t]{3}{*}{8} & Pendidikan Ibu & & & & & & & & \\
\hline & - $\quad$ Rendah & 71 & 39,0 & 35 & 19,2 & 106 & 29,1 & 2,686 & $<0,001$ \\
\hline & - $\quad$ Tinggi & 111 & 61,0 & 147 & 80,8 & 258 & 70,9 & $(1,6-4,3)$ & \\
\hline \multirow[t]{3}{*}{9} & Pekerjaan Ibu & & & & & & & & \\
\hline & - Bekerja & 64 & 35,2 & 66 & 36,3 & 130 & 35,7 & 0,953 & 0,913 \\
\hline & - $\quad$ Tidak bekerja & 118 & 64,8 & 116 & 63,7 & 234 & 64,3 & $(0,6-1,4)$ & \\
\hline \multirow[t]{3}{*}{10} & Jenis kelamin & & & & & & & & \\
\hline & - $\quad$ Laki-laki & 120 & 65,9 & 114 & 62,6 & 234 & 64,3 & 1,154 & 0,584 \\
\hline & Perempuan & 62 & 34,1 & 68 & 37,4 & 130 & 35,7 & $(0,7-1,7)$ & \\
\hline
\end{tabular}




\section{Analisis Multivariat}

Hasil analisis multivariat dapat disimpulkan bahwa variabel independen yang dominan adalah kebiasaan merokok di dalam rumah, pendidikan ibu, pemberian ASI Eksklusif, luas ventilasi dan pemberian vitamin A. Variabel status imunisasi DPT dan berat bada lahir merupakan variabel confounding.

Tabel 2 Pemodelan Akhir

\begin{tabular}{llclc}
\hline \multirow{2}{*}{ No } & Variabel & P value & Exp(B) & $\begin{array}{c}\text { 95\%CI.for } \\
\text { EXP(B) }\end{array}$ \\
\cline { 4 - 5 } & & & Lower - Upper \\
\hline 1 & Pemberian ASI Eksklusif & 0,008 & 2,374 & $1,249-4,512$ \\
2 & Status Imunisasi DPT* & 0,218 & 1,793 & $0,708-4,543$ \\
3 & Pemberian vitamin A & 0,001 & 2,842 & $1,559-5,181$ \\
4 & Kebiasaan merokok di & 0,000 & 5,014 & $2,941-8,548$ \\
& dalam rumah & & & \\
5 & Luas ventilasi & 0,000 & 3,645 & $1,853-7,168$ \\
6 & Berat badan lahir* & 0,998 & 889491799,7 & 0,000 \\
7 & Pendidikan ibu & 0,000 & 3,160 & $1,681-5,940$ \\
\hline Omnibus test of model coefficient $\mathbf{= 0 , 0 0 0}$ & Nagelkerke $\boldsymbol{R}$ Square $=\mathbf{0 , 4 7 3}$ \\
\hline *ariabel confounding & \multicolumn{3}{l}{}
\end{tabular}

\section{PEMBAHASAN}

\section{Kebiasaan Merokok di dalam Rumah}

Dalam penelitian ini kebiasaan merokok di dalam rumah berhubungan dengan kejadian ISPA pada bayi usia 6-12 bulan di Puskesmas Rawat Inap Simpang Tiga Pekanbaru.

Bahan berbahaya dalam rokok tidak hanya mengakibatkan gangguan kesehatan kepada perokok, juga kepada orang-orang disekitarnya yang tidak merokok terutama bayi yang terpaksa menjadi perokok pasif oleh karena adanya anggota keluarga mereka yang merokok di dalam rumah (Fitriana, 2015). Bayi yang sering menghisap asap rokok lebih mudah terserang ISPA. Hal ini dikarenakan bayi lebih rentan terhadap efek polutan. Adanya pencemaran udara di dalam rumah yang disebabkan oleh asap rokok dapat merusak mekanisme pertahanan paru-paru, sehingga mempermudah timbulnya gangguan saluran pernapasan (Nuryanto, 2010).

Hasil penelitian ini sejalan dengan hasil penelitian Rustam (2010) yang menyatakan bahwa terdapat hubungan yang signifikan antara adanya perokok dengan kejadian ISPA (OR= 3,08: $95 \%$ CI: 1,69-5,71).

Bila merokok di dalam rumah, maka berpengaruh lima kali terhadap kejadian ISPA pada bayi usia 6-12 bulan dibandingkan dengan tidak merokok di dalam rumah. Anggota keluarga yang memiliki kebiasaan merokok di dalam rumah, bayi mereka lebih banyak yang terkena ISPA dibandingkan dengan anggota keluarga yang tidak merokok di dalam rumah. Oleh karena itu, direkomendasikan agar bayi tidak terkena paparan asap rokok, maka diupayakan orangtua yang memiliki bayi untuk tidak merokok di dalam rumah. 


\section{Pendidikan Ibu}

Pendidikan ibu berhubungan dengan kejadian ISPA pada bayi usia 6-12 bulan di Puskesmas Rawat Inap Simpang Tiga Pekanbaru.

Secara teoritis tingkat pendidikan yang rendah adalah salah satu faktor yang menyebabkan kurangnya pengetahuan. Ibu yang berpengetahuan rendah mengenai ISPA cenderung akan berperilaku tidak sehat yang berisiko untuk terjadinya ISPA. Perilaku ibu yang tidak menutup hidung dan mulut ketika batuk dan bersin, memungkinkan terjadinya penularan penyakit ISPA pada bayi, dimana pola penyebaran ISPA yang utama adalah melalui droplet yang keluar dari hidung dan mulut saat batuk atau bersin (Sundari dkk, 2014).

Hasil penelitian ini sejalan dengan penelitian yang dilakukan Widarini (2010) di Puskesmas Mengwi II, bahwa tingkat pendidikan ibu yang rendah bayi mereka mempunyai risiko 2 kali lebih besar terkena ISPA dibandingkan tingkat pendidikan ibu yang tinggi (OR= 2,00:95\% CI : 0,722-5,184).

Berdasarkan hasil penelitian ini, bila tingkat pendidikan ibu rendah, maka berpengaruh 3,2 kali terhadap kejadian ISPA dibandingkan dengan ibu yang tingkat pendidikannya tinggi. Ibu dengan tingkat pendidikan rendah, bayi mereka lebih banyak yang terkena ISPA dibandingkan ibu dengan tingkat pendidkan tinggi. Oleh karena itu direkomendasikan agar melakukan kegiatan promosi kesehatan, terutama pada ibu yang berpendidikan rendah supaya ibu tidak melakukan perilaku tidak sehat yang berisiko menularkan ISPA kepada bayi mereka.

\section{Pemberian ASI Eksklusif}

Dalam penelitian ini ditemukan bahwa Pemberian ASI Eksklusif berhubungan dengan kejadian ISPA pada bayi usia 6-12 bulan dengan berat badan lahir dan status imunisasi DPT sebagai confounding.

Pemberian ASI Eksklusif bagi bayi untuk mencegah penyakit infeksi karena ASI memiliki zat protektif atau zat imun. Berbeda dengan bayi yang tidak diberi ASI secara Eksklusif akan kehilangan zat protektif yang terkandung di dalam ASI sehingga rentan untuk terkena penyakit infeksi (Syahriah, 2014). Zat protektif yang memiliki peran penting dalam melindungi tubuh dari ISPA adalah sIgA (secretory $\operatorname{IgA}$ ). sIgA berfungsi sebagai antibodi dari mikroorganisme patogen yang menyebabkan ISPA (Nirwana, 2014).

Hasil penelitian ini sejalan dengan penelitian yang dilakukan oleh Widarini (2010), bahwa risiko untuk terjadinya ISPA pada bayi yang tidak diberi ASI Eksklusif sebesar 4,96 kali lebih besar dibandingkan bayi yang diberi ASI Eksklusif $(\mathrm{OR}=4,690: 95 \%$ CI : 1,56915,677).

Berdasarkan hasil penelitian, sebagian besar bayi yang tidak diberikan ASI Eksklusif lebih banyak yang menderita ISPA. Bila tidak diberi ASI Eksklusif pada bayi usia 6-12 bulan, maka berpengaruh 2,4 kali terhadap kejadian ISPA dibandingkan dengan bayi usia 6-12 bulan yang diberi ASI Eksklusif. Oleh karena itu, direkomendasikan agar tidak terjadi ISPA pada bayi, maka bayi diberikan imunisasi DPT dan ASI Eksklusif untuk menambah berat badan lahirnya sehingga dapat mencegah terjadinya ISPA. bayinya.

\section{Luas Ventilasi}


Hasil penelitian ini menunjukkan bahwa luas ventilasi berhubungan dengan kejadian ISPA pada bayi usia 6-12 bulan di Puskesmas Rawat Inap Simpang Tiga Pekanbaru.

Ventilasi berfungsi untuk membebaskan udara ruangan dari bakteri terutama bakteri patogen. Bakteri yang terbawa oleh udara akan selalu mengalir. Selain itu fungsi lainnya adalah untuk menjaga agar ruangan selalu tetap didalam kelembaban yang optimum (Mundiatun, 2014). Ukuran ventilasi yang memenuhi syarat adalah sebesar $10 \%$ dari luas lantai. Ventilasi rumah berkaitan dengan kelembaban rumah yang mendukung daya hidup virus maupun bakteri. Dengan pencahayaan yang memadai akan mengurangi risiko terjadinya ISPA pada bayi. Hal ini disebabkan sinar matahari yang masuk ke dalam rumah dapat membunuh bakteri atau virus penyebab ISPA (Winardi dkk, 2016).

Peneltian ini sejalan dengan hasil penelitian Winardi, dkk (2016), yang menyatakan bahwa bayi yang memiliki luas ventilasi kamar tidak memenuhi syarat, maka 6,8 kali berisiko untuk terkena ISPA dari pada bayi yang memiliki luas ventilasi kamar memenuhi syarat (OR=6,8: 95\%CI 2,450-18,875).

Adanya hubungan antara luas ventilasi rumah dengan kejadian ISPA pada bayi usia 6-12 bulan, hal ini dikarenakan bayi yang tinggal di rumah dengan luas ventilasi yang tidak memenuhi syarat, lebih banyak yang menderita ISPA dibandingkan bayi yang tinggal di rumah dengan luas ventilasi yang memenuhi syarat kesehatan. Bila luas ventilasi rumah tidak memenuhi syarat $(<10 \%)$, maka berpengaruh 3,6 kali terhadap kejadian ISPA dibandingkan dengan luas ventilasi rumah yang memenuhi syarat $(\geq 10 \%)$.
Oleh karena itu, direkomendasikan bagi rumah yang luas ventilasinya tidak memenuhi syarat $(<10 \%)$, agar membuka jendela setiap hari agar sinar matahari pagi masuk sehingga suhu ruangan kembali seimbang dan sirkulasi udara dalam rumah terjaga dengan baik.

\section{Pemberian vitamin A}

Dalam penelitian ini, pemberian vitamin $A$ berhubungan dengan kejadian ISPA pada bayi usia 6-12 bulan dengan status imunisasi DPT dan berat badan lahir sebagai confounding.

Pemberian kapsul vitamin A yang secara rutin sangat berperan meningkatkan respon antibodi terhadap toksoid. Salah satu khasiat vitamin A dapat meningkatkan daya tahan tubuh terhadap penyakit infeksi seperti ISPA (Utami, 2013). Kekurangan vitamin A akan menyebabkan keratinisasi mukosa saluran pernapasan dan penurunan fungsi cilia serta sekresi mukus pada sel epitel saluran pernapasan sehingga akan menyebabkan tubuh terkena infeksi (Widjaja, 2010).

Hasil penelitian ini sejalan dengan hasil penelitian Agusta (2013) bahwa terdapat hubungan antara pemberian vitamin A dengan kejadian ISPA $(\mathrm{p}=0,013)$ di Puskesmas Calang.

Adanya hubungan antara pemberian vitamin A dengan kejadian ISPA, hal ini dikarenakan sebagian besar bayi usia 6-12 bulan yang belum diberikan vitamin A lebih banyak terkena ISPA dibandingkan bayi usia 6-12 bulan yang sudah diberikan vitamin A. Bila belum diberikan vitamin A pada bayi usia 6-12 bulan, maka berpengaruh 2,8 kali terhadap kejadian ISPA dibandingkan dengan bayi usia 6-12 bulan yang sudah diberikan vitamin A. Oleh karena itu, direkomendasikan agar tidak terjadi ISPA pada bayi, maka bayi 
diberikan imunisasi DPT dan vitamin A untuk menambah berat badan lahirnya sehingga dapat mencegah terjadinya ISPA.

\section{KESIMPULAN DAN SARAN}

\section{Kesimpulan}

Berdasarkan hasil penelitian maka dapat disimpulkan bahwa :

1. Variabel yang berhubungan sebab akibat dengan kejadian ISPA pada bayi usia 6-12 bulan, yaitu :

a. Kebiasaan merokok di dalam rumah : merokok di dalam rumah, berpengaruh 5 kali terhadap kejadian ISPA pada bayi usia 6-12 bulan dibandingkan dengan tidak merokok di dalam rumah (CI 95\% : $\mathrm{OR}=2,9-8,5)$

b. Pendidikan Ibu : pendidikan ibu yang rendah (SMP ke bawah), berpengaruh 3,2 kali terhadap kejadian ISPA dibandingkan dengan ibu yang berpendidikan tinggi (SMA ke atas) (CI 95\%: OR $=1,6-5,9)$

c. Pemberian ASI Eksklusif : tidak diberi ASI Eksklusif pada bayi usia 6-12 bulan, berpengaruh 2,4 kali terhadap kejadian ISPA dibandingkan dengan diberi ASI Eksklusif pada bayi usia 6-12 bulan (CI 95\%: OR = 1,2-4,5)

d. Luas ventilasi : luas ventilasi rumah yang tidak memenuhi syarat $(<10 \%)$, berpengaruh 3,6 kali terhadap kejadian ISPA dibandingkan dengan luas ventilasi rumah yang memenuhi syarat $(\geq 10 \%)(\mathrm{CI} 95 \%$ : OR $=1,8-7,1)$

e. Pemberian vitamin $A$ : belum diberikan vitamin A pada bayi usia 6-12 bulan,berpengaruh 2,8 kali terhadap kejadian ISPA dibandingkan dengan sudah diberikan vitamin A pada bayi usia 6-12 bulan (CI 95\% : OR $=1,5-$ $5,1)$

2. Variabel confounding yaitu 1) variabel berat badan lahir confounding terhadap pemberian ASI Eksklusif dan status imunisasi DPT; 2) status imunisasi DPT confounding terhadap pemberian vitamin $A$ dan berat badan lahir.

3. Variabel yang tidak berhubungan dengan kejadian ISPA pada bayi usia 6-12 bulan yaitu status gizi bayi, pekerjaan ibu dan jenis kelamin.

\section{Saran}

\section{Bagi Puskesmas Rawat Inap Simpang Tiga Pekanbaru}

Diharapkan kepada pihak Puskesmas lebih meningkatkan pelayanan dibidang promosi kesehatan dengan cara menyediakan media informasi seperti poster, leaflet, brosur tentang bahaya merokok di dalam rumah, pentingnya pemberian ASI Eksklusif, imunisasi DPT, pemberian vitamin A serta menganjurkan agar selalu membuka jendela di pagi hari sehingga ISPA pada bayi dapat dicegah. Selain itu petugas puskesmas dan kader posyandu diharapkan turut berperan aktif melakukan kunjungan rumah kepada ibu yang jarang datang ke Posyandu dan menganjurkan agar rutin memeriksakan kesehatan bayinya.

\section{Bagi Penelitian Selanjutnya}

Bagi penelitian selanjutnya yang ingin mengembangkan penelitian ini variabel status gizi bayi, pada penelitian selanjutnya status gizi bayi menggunakan data primer dan menambahkan pertanyaan pada kuesioner. Pertanyaan dibuat sejelas mungkin untuk menghindari bias 
informasi. Untuk variabel pekerjaan Ibu, pada penelitian selanjutnya penyusunan pertanyaan pada kuesioner lebih terfokus pada rutinitas ibu sehari-hari untuk pengkategorian bekerja dan tidak bekerja, seperti ibu bekerja adalah ibu yang lebih banyak beraktivitas di luar rumah sedangkan ibu yang tidak bekerja adalah ibu yang lebih banyak menghabiskan waktu dengan anaknya dan beraktivitas di dalam rumah. Untuk variabel jenis kelamin, perlu dilakukan penelitian lebih lanjut tentang perbedaan hormon antara bayi laki-laki dan perempuan terhadap kejadian ISPA.

\section{DAFTAR PUSTAKA}

Agusta, Mona. (2015). Faktor-Faktor Yang Berhubungan Dengan Kejadian Penyakit Infeksi Saluran Pernafasan Akut (ISPA) Pada Anak Balita yang Berkunjung ke Puskesmas Calang Kecamatan Krueng Sabee Kabupaten Aceh Jaya. Skripsi. Program Studi Kesehatan Masyarakat Fakultas Kesehatan Masyarakat Universitas Teuku Umar. Meulaboh.

Fitriana D, Damayanti \& Nuzrina R. (2015). Hubungan status gizi, riwayat pemberian vitamin $\mathrm{A}$, riwayat imunisasi (BCG, DPT, Campak) dan kebiasaan merokok anggota keluarga dengan kejadian ISPA pada balita usia 1-4 tahun di Provinsi Nangroe Aceh Darussalam (analisis data sekunder riskesdas 2007). Nutrire Diaita. 7 (2), 91-98.

Masriadi. (2017). Epidemiologi Penyakit Menular. Cetakan ke 2. Depok: PT RajaGrafindo Persada
Mundiatun, D. (2014). Pengelolaan Kesehatan Lingkungan. Yogyakarta: Gava Media.

Dinas Kesehatan Kota Pekanbaru. (2016). Rekap Laporan Pengendalian ISPA. Pekanbaru

Marni. (2014). Asuhan Keperawatan pada Anak Sakit dengan Gangguan Pernapasan. Yogyakarta: Gosyen Publishing.

Kemenkes RI. (2013). Riset Kesehatan Dasar. Jakarta : Lembaga Penerbitan Badan Penelitian dan Pengembangan Kesehatan Kementerian Kesehatan RI

Kemenkes RI. (2013). Pokok-Pokok Hasil Riset Kesehatan Dasar Provinsi Riau. Jakarta :Lembaga Penerbitan Badan Penelitian dan Pengembangan Kesehatan Kementerian Kesehatan RI

Najmah. (2016). Epidemiologi Penyakit Menular. Jakarta Timur: CV. Trans Info Media.

Nirwana. AB. (2014). ASI dan Susu Formula. Yogyakarta: Nuha Medika Nuryanto. (2010). Beberapa Faktor yang Berhubungan dengan Penyakit Infeksi Saluran Pernapasan Akut (ISPA) pada Balita. Jurnal Pembangunan Manusia. 4(11).

Rustam, M. (2010). Hubungan Pemberian ASI Eksklusif Terhadap Kejadian ISPA Pada Bayi Usia 6-12 Bulan di Kabupaten Kampar Provinsi Riau. Tesis. Program Studi Pasca Sarjana Epidemiologi Fakultas Kesehatan Masyarakat Universitas Indonesia. Jakarta. 
Sundari S, Pratiwi, Khairudin. (2014). Perilaku Tidak Seha Ibu yang Menjadi Faktor Risiko Terjadinya ISPA Pneumonia pada Balita. Jurnal Pendidikan Sains, 2(3), 141147.

Syahriah, U. (2014). Hubungan Usia Pemberian MP-ASI dan Usia Penyapihan dengan Status Gizi Anak Usia 0-24 Bulan di Desa Kalijaga Timur Kecamatan Aikmel Kabupaten Lombok Timur. Tesis. Ungaran: Prodi Ilmu Gizi STIKes Ngudi Waluyo.

Tosepu, R. (2016). Epidemiologi Lingkungan Teori Dan Aplikasi. Jakarta: Bumi Medika

Utami, S. (2013). Studi Deskriptif Pemetaan Faktor Risiko ISPA Pada Balita Usia 0-5 Tahun Yang Tinggal di Rumah Hunian Akibat Bencana Lahar Dingin Merapi di Kecamatan Salam Kabupaten Magelang.
Fakultas Ilmu Keolahragaan. Semarang: Universitas Negeri Semarang.

Widarini NP \& Sumasari NL. (2010). Hubungan Pemberian ASI Eksklusif Dengan Kejadian ISPA Pada Bayi. Jurnal Ilmu Gizi, 1(1), 28-41.

Winardi, W., Umboh, J., Rattu, A. (2016). Hubungan Antara Kondisi Lingkungan Rumah Dengan Kejadian Penyakit ISPA Pada Anak Balita Di Wilayah Kerja Puskesmas Sario Kecamatan Sario Kota Manado. Manado: Universitas Sam Ratulangi

Widjaja A \& Susi N. (2010). Penanganan ISPA pada Anak di Rumah Sakit Kecil Negara Berkembang. Jakarta: EGC

Wijayaningsih, K S. (2013). Asuhan Keperawatan Anak. Jakarta Timur: CV. Trans Info Media. 